American Journal of Applied Sciences 7 (5): 628-633, 2010

ISSN 1546-9239

(C) 2010Science Publications

\title{
Synthesis and Characterization of Dinuclear Metal Complexes Stabilized by Tetradentate Schiff Base Ligands
}

\author{
${ }^{1}$ Eid A. Abdalrazaq, ${ }^{2}$ Omar M. Al-Ramadane and ${ }^{2}$ Khansa S. Al-Numa \\ ${ }^{1}$ Department of Chemistry, College of Science, Al-Hussein Bin Talal \\ University Ma'an, Jordan \\ ${ }^{2}$ Department of Chemistry, College of Science, Mosul University, Iraq
}

\begin{abstract}
Problem statement: The synthesis, spectroscopic properties and theoretical calculations of acetylacetonimine and acetylacetanilidimine Schiff-base ligands, $\mathrm{L}_{1} \mathrm{H}$ and $\mathrm{L}_{2} \mathrm{H}$, respectively and their dinuclear complexes of the type $\left[\mathrm{M}_{2} \mathrm{~L}_{\mathrm{n}} \mathrm{Cl}_{2}\left(\mathrm{H}_{2} \mathrm{O}\right)_{2}\right]$, where $\mathrm{n}=1$ or $2, \mathrm{M}=\mathrm{Co}(\mathrm{II}), \mathrm{Ni}(\mathrm{II}), \mathrm{Cu}(\mathrm{II}), \mathrm{Zn}(\mathrm{II})$ and $\mathrm{Cd}(\mathrm{II})$ are described. Approach: The new tetradentate dianion Schiff base ligand which was used as stabilizers for the complexes were prepared by condensation of hydrazine with acetylacetone or acetylacetanilide. The dinuclear complexes of theses ligands were synthesized by treating an ethanolic solution of the prepared ligand with hydrated metal salts in molar ratio of 1:2 (L:M). Results: The ligand and their dinuclear metal complexes were characterized by CHN elemental analysis, FT-IR, UV-Vis, ${ }^{1} \mathrm{HNMR}$ (for the ligands), conductivity, magnetic susceptibility and theoretical calculation by using MM2 modeling program. Conclusion: The reaction of these ligands in a 1:2 (L:M) afford dinuclear $\mathrm{M}(\mathrm{II})$ metal complexes with tetrahedral arrangement around $\mathrm{Co}(\mathrm{II}), \mathrm{Zn}(\mathrm{II})$ and $\mathrm{Cd}(\mathrm{II})$ and square planar around $\mathrm{Ni}(\mathrm{II})$ and $\mathrm{Cu}(\mathrm{II})$.
\end{abstract}

Key words: Schiff base, hydrazine, acetoacetanilide, acetyl acetone, dinuclear complexes

\section{INTRODUCTION}

A great deal of work has been reported on the synthesis and characterization of different types of Schiff base complexes with transition and non transition elements (Vigato et al., 2007; De Geest et al., 2007; Knight et al., 2007).

The majority of Schiff bases usually act as multidentate $\mathrm{N}-\mathrm{N}$ and $\mathrm{N}-\mathrm{O}$ donors with the formation of mono-or polynuclear complexes (De Geest et al., 2007; Rai and Sharma, 1995; Maurya et al., 1995).

In addition to their interesting ligational properties, both Schiff bases and their complexes have important biological and industrial applications (Al-Razaq et al., 2005; Bedioui, 1995; Brown et al., 1995).

The preparation of anionic and neutral dimeric complexes of the general formula $\left[\mathrm{Ni}(\mathrm{phen})_{3}\right]\left[\mathrm{ML}_{2}\right]$ were phen $=1,10$-phenanthroline, $\mathrm{L}=2$ mercaptoethylamine-N-salicylaldimine and 2mercaptoethylamine- $\mathrm{N}$-acetylacetoneimine, $\mathrm{M}=\mathrm{Ni}(\mathrm{II})$, $\mathrm{Cu}(\mathrm{II})$ and $\mathrm{Zn}(\mathrm{II})$ and $\left[\mathrm{M}_{2} \mathrm{~L}_{2}\right]$ were $\mathrm{M}=\mathrm{Co}(\mathrm{II}), \mathrm{Ni}(\mathrm{II})$, $\mathrm{Cu}(\mathrm{II})$ and $\mathrm{Zn}(\mathrm{II})$ and their physico-chemical characterization.

The aim of the present research is the synthesis and physicochemical study of new cobalt(II), nickel(II),
copper(II), zinc(II) and cadmium(II) coordination complexes with new Schiff bases ligands.

\section{MATERIALS AND METHODS}

General: $\left[\mathrm{CoCl}_{2} \cdot 6 \mathrm{H}_{2} \mathrm{O}\right],\left[\mathrm{NiCl}_{2} \cdot 6 \mathrm{H}_{2} \mathrm{O}\right],\left[\mathrm{CuCl}_{2} \cdot 2 \mathrm{H}_{2} \mathrm{O}\right]$, $\left[\mathrm{ZnCl}_{2}\right]$ and $\left[\mathrm{CdCl}_{2}\right]$ the remaining reagents were products from (BDH or Fluka) and used as supplied. The metal content was estimated spectrophotometrically using Shimadzu Atomic Absorption 670 Spectrophotometer. The prepared compounds were analyzed by using the $\mathrm{C}, \mathrm{H}, \mathrm{N}$ elemental analyzer (Carlo Erba). Melting points were determined using Buchi 510 melting point apparatus. Infrared spectra were recorded using Perkin Elmer 580 spectrophotometr in the range $4000-200 \mathrm{~cm}^{-1}$ as $\mathrm{KBr}$ pellets. The ${ }^{1} \mathrm{H}$ NMR spectra were recorded on a Bruker- Avence $300 \mathrm{MHz}$ spectrometer in DMSO- $\mathrm{d}_{6}$ at room temperature. The electronic spectra were recorded on Shimadzu UV. Visible spectrophotometer UV-160 for $10^{-3} \mathrm{M}$ solution of the complexes in DMSO at $25^{\circ} \mathrm{C}$ using $1 \mathrm{~cm}$ quartz conductivity measurements were carried out on $10^{-3} \mathrm{M}$ solution of the complexes in DMSO using $\left(\mathrm{PMC}_{3}\right.$ (Jenway) conductivity model) at room temperature. Magnetic measurements were

Corresponding Author: Eid A. Abdalrazaq, Department of Chemistry, College of Science, Al-Hussein Bim Tala University Ma'an, Jordan 
carried out on the solids by the Faradys method using Bruker BM6 instrument and AA670 for the determination of metal content.

Theoretical computation was applied on the suggested structures of the prepared complexes using MM2CS ChemOffice version 11.0 by Pentium (IV) computer.

Preparation of the Schiff base compounds: About $0.40 \mathrm{~mol}$ of acetylacetone or acetylacetanilide was added to $25 \mathrm{~mL}$ of absolute ethanol along with $0.20 \mathrm{~mol}$ of hydrazine. After adding a few drops of glacial acetic acid, the mixture was refluxed for $3 \mathrm{~h}$ and then cooled to room temperature. Some amount of distilled water was then added to the solution and the whole solution was cooled in ice. A yellow solid gradually appeared which was allowed to stand for nearly 30 min during which a considerable amount of solid was formed and settled down. It was filtered, washed thoroughly with a small amount of distilled water and then dried in air and finally in vacuum.

Preparation of the complexes: Aqueous solution of $0.004 \mathrm{~mol}$ of $\mathrm{MCl}_{2} \cdot \mathrm{nH}_{2} \mathrm{O}$, where $\mathrm{M}=\mathrm{Co}(\mathrm{II}), \mathrm{Ni}(\mathrm{II})$, $\mathrm{Cu}(\mathrm{II}), \mathrm{Zn}(\mathrm{II})$ and $\mathrm{Cd}(\mathrm{II})$ was added to an athanolic solution of $0.002 \mathrm{~mol}$ of the ligand. The mixture was stirred at room temperature for $40 \mathrm{~min}$ and warmed on water bath for $4 \mathrm{~h}$. On standing overnight, the precipitated product was obtained which was filtered, washed with water, then with ethanol and recrystallized from hot alcoholic solution. The product was then washed with ethanol, ether and dried in vacuum for $3 \mathrm{~h}$.

Theoretical calculations: The optimized geometry and steric energy of the prepared complexes were done using MM2CS ChemOffice 11.0 molecular modeling program package. These calculations were performed using computer Pentium (IV) with processor operating at $2400 \mathrm{MHz}$.

\section{RESULTS}

The reaction of the Schiff base ligands with metal chloride in (1:2) ligand to metal molar ratio afford the complexes of the general formula $\left[\mathrm{M}_{2}\left(\mathrm{~L}_{1}\right) \mathrm{Cl}_{2}\left(\mathrm{H}_{2} \mathrm{O}\right)_{2}\right]$ and $\left[\mathrm{M}_{2}\left(\mathrm{~L}_{2}\right) \mathrm{Cl}_{2}\left(\mathrm{H}_{2} \mathrm{O}\right)_{2}\right]$ as shown in Fig. 1 and 2, respectively. The physical properties of the complexes are tabulated in Table 1 and the elemental analysis data which are listed in Table 2 for ligands and complexes assigned to 1: 2 molar ratio of shciff base ligand: $\mathrm{M}$. They are quite stable in air and melt or decompose above $170^{\circ} \mathrm{C}$. They are insoluble in most organic solvent but soluble in DMF and DMSO.
Conductivity measurements: The molar conductivities of $10^{-3} \mathrm{M}$ solution of the complexes listed in Table 1 indicate that all complexes are non electrolyte in DMSO (Geary, 1971).

IR-spectra: The most important IR assignments of the complexes are listed in Table 3. There are some bands appeared in the complex spectra which are attributed to $\mathrm{M}-\mathrm{O}$ and $\mathrm{M}-\mathrm{N}$, this bands confirm the complex formation.<smiles>C/C(O)=C/C(=N/Nc1ccccc1)Nc1ccccc1</smiles>

$\mathrm{H}_{2} \mathrm{~L}_{1}$<smiles>C/C(O)=C/C(C)=N/N=C(C)/C=C(\C)O</smiles>

Fig. 1: The suggested structures of the free Schiff bases ligands
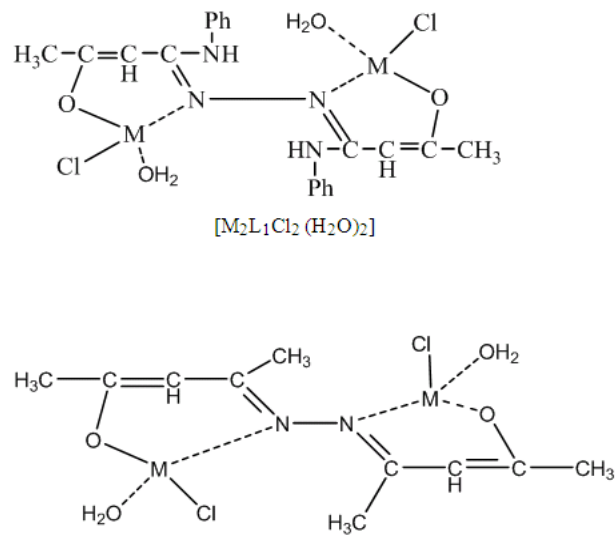

$\left[\mathrm{M}_{2} \mathrm{~L}_{2} \mathrm{Cl}_{2}\left(\mathrm{H}_{2} \mathrm{O}\right)_{2}\right]$

Fig. 2: The suggested structures of the prepared complexes; $\mathrm{M}=\mathrm{Co}(\mathrm{II}), \mathrm{Ni}(\mathrm{II}), \mathrm{Cu}(\mathrm{II}), \mathrm{Zn}(\mathrm{II})$, Cd(II) 
Am. J. Applied Sci., 7 (5): 628-633, 2010

Table 1: Physical properties of the free ligands and complexes

\begin{tabular}{llllll}
\hline Seq. & Compound & Color & m.p. $\left({ }^{\circ} \mathrm{C}\right)$ & $\mathrm{A}_{\mathrm{M}}\left(\mathrm{ohm}^{-1} . \mathrm{cm}^{2} \mathrm{~mol}^{-1}\right)$ & $\mu_{\text {eff }}$ B.M. \\
\hline & $\mathrm{H}_{2} \mathrm{~L}_{1}$ & Yellow & 122 & - & - \\
& $\mathrm{H}_{2} \mathrm{~L}_{2}$ & Pale yellow & 135 & - & - \\
1 & {$\left[\mathrm{Co}_{2} \mathrm{~L}_{1} \mathrm{Cl}_{2}\left(\mathrm{H}_{2} \mathrm{O}\right)_{2}\right]$} & Dark brown & 138 & 15.3 & $4.22^{* *}$ \\
2 & {$\left[\mathrm{Ni}_{2} \mathrm{~L}_{1} \mathrm{Cl}_{2}\left(\mathrm{H}_{2} \mathrm{O}\right)_{2}\right]$} & Green & 149 & 10.8 & Dia \\
3 & {$\left[\mathrm{Cu}_{2} \mathrm{~L}_{1} \mathrm{Cl}_{2}\left(\mathrm{H}_{2} \mathrm{O}\right)_{2}\right]$} & Yellow-green & $172^{*}$ & 18.1 & $1.61^{* *}$ \\
4 & {$\left[\mathrm{Zn}_{2} \mathrm{~L}_{1} \mathrm{Cl}_{2}\left(\mathrm{H}_{2} \mathrm{O}\right)_{2}\right]$} & White & 166 & 19.6 & - \\
5 & {$\left[\mathrm{Cd}_{2} \mathrm{~L}_{1} \mathrm{Cl}_{2}\left(\mathrm{H}_{2} \mathrm{O}\right)_{2}\right]$} & White & 151 & 12.6 & - \\
6 & {$\left[\mathrm{Co}_{2} \mathrm{~L}_{2} \mathrm{Cl}_{2}\left(\mathrm{H}_{2} \mathrm{O}\right)_{2}\right]$} & Red-brown & 160 & 14.2 & $4.01^{* *}$ \\
7 & {$\left[\mathrm{Ni}_{2} \mathrm{~L}_{2} \mathrm{Cl}_{2}\left(\mathrm{H}_{2} \mathrm{O}\right)_{2}\right]$} & Blue & 142 & Dia \\
8 & {$\left[\mathrm{Cu}_{2} \mathrm{~L}_{2} \mathrm{Cl}_{2}\left(\mathrm{H}_{2} \mathrm{O}\right)_{2}\right]$} & Pink & $196^{*}$ & 9.3 & $1.80^{* *}$ \\
9 & {$\left[\mathrm{Zn}_{2} \mathrm{~L}_{2} \mathrm{Cl}_{2}\left(\mathrm{H}_{2} \mathrm{O}\right)_{2}\right]$} & White & 190 & 21.0 & - \\
10 & {$\left[\mathrm{Cd}_{2} \mathrm{~L}_{2} \mathrm{Cl}_{2}\left(\mathrm{H}_{2} \mathrm{O}\right)_{2}\right]$} & white & $203^{*}$ & 11.7 & - \\
\hline
\end{tabular}

*: Decomposition; **: Per metal atom

Table 2: elemental analysis of the ligands and complexes

\begin{tabular}{llllll}
\hline & \multicolumn{5}{c}{ Elemental analysis: Percentage of found (Clac.) } \\
Compound & Yield (\%) & M (\%) & C (\%) & H (\%) & N (\%) \\
\hline $\mathrm{H}_{2} \mathrm{~L}_{1}$ & 72.10 & - & $68.20(68.57)$ & $6.19(6.29)$ & $15.70(16.00)$ \\
$\mathrm{H}_{2} \mathrm{~L}_{2}$ & 69.65 & - & $61.00(61.22)$ & $8.03(8.16)$ & $13.90(14.29)$ \\
1 & 54.02 & $20.22(20.57)$ & $41.40(41.90)$ & $4.02(4.54)$ & $9.82(9.78)$ \\
2 & 63.70 & - & $41.00(41.93)$ & $4.02(4.54)$ & $9.57(9.78)$ \\
3 & 71.31 & $21.66(21.84)$ & $41.60(41.23)$ & $4.16(4.47)$ & $9.63(9.62)$ \\
4 & 68.91 & - & $40.70(40.98)$ & $4.06(4.44)$ & $9.45(9.56)$ \\
5 & 79.22 & $32.96(33.07)$ & $35.10(35.31)$ & $3.32(3.83)$ & $8.01(8.24)$ \\
6 & 66.83 & - & $28.50(28.66)$ & $4.25(4.78)$ & $6.49(6.69)$ \\
7 & 65.68 & $27.90(28.07)$ & $27.60(28.69)$ & $4.15(4.78)$ & $6.34(6.69)$ \\
8 & 70.11 & - & $28.80(28.04)$ & $4.19(4.67)$ & $6.23(6.54)$ \\
9 & 76.40 & $29.88(30.29)$ & $27.60(27.80)$ & $4.19(4.63)$ & $6.30(6.48)$ \\
10 & 62.32 & - & $22.70(22.83)$ & $3.20(3.80)$ & $5.00(3.35)$ \\
\hline
\end{tabular}

Table 3: IR spectra $\left(\mathrm{cm}^{-1}\right)$ and electronic spectra of the ligands and complexes

\begin{tabular}{llllllll}
\hline Seq. & $v(\mathrm{C}=\mathrm{N})$ & $v(\mathrm{C}-\mathrm{O})$ & $v(\mathrm{M}-\mathrm{N})$ & $v(\mathrm{M}-\mathrm{O})$ & $v(\mathrm{M}-\mathrm{Cl})$ & $v\left(\mathrm{M}-\mathrm{OH}_{2}\right)$ & $\mathrm{M}_{\max }(\mathrm{UV})$ \\
\hline $\mathrm{H}_{2} \mathrm{~L}_{1}$ & $1642(\mathrm{~m})$ & $1243(\mathrm{~m})$ & - & - & - & - & - \\
$\mathrm{H}_{2} \mathrm{~L}_{2}$ & $1638(\mathrm{~m})$ & $1236(\mathrm{w})$ & - & - & - & - & - \\
1 & $1632(\mathrm{w})$ & $1213(\mathrm{~m})$ & $366(\mathrm{w})$ & $496(\mathrm{w})$ & $272(\mathrm{~m})$ & $418(\mathrm{~m})$ & 13800 \\
2 & $1621(\mathrm{w})$ & $1210(\mathrm{~m})$ & $416(\mathrm{w})$ & $486(\mathrm{w})$ & $286(\mathrm{~m})$ & $491(\mathrm{w})$ & $15386,15396,16000,20820,21146$ \\
3 & $1618(\mathrm{~s})$ & $1218(\mathrm{~m})$ & $422(\mathrm{~s})$ & $512(\mathrm{~s})$ & $293(\mathrm{~m})$ & $476(\mathrm{~s})$ & $13403,14612,15860$ \\
4 & $1628(\mathrm{~s})$ & $1232(\mathrm{~s})$ & $373(\mathrm{~s})$ & $504(\mathrm{~m})$ & $315(\mathrm{~m})$ & $510(\mathrm{w})$ & - \\
5 & $1612(\mathrm{~m})$ & $1226(\mathrm{w})$ & $395(\mathrm{w})$ & $520(\mathrm{~m})$ & $320(\mathrm{~m})$ & $466(\mathrm{w})$ & - \\
6 & $1622(\mathrm{~m})$ & $1203(\mathrm{w})$ & $406(\mathrm{~m})$ & $492(\mathrm{~m})$ & $296(\mathrm{w})$ & $446(\mathrm{~m})$ & 13815 \\
7 & $1625(\mathrm{~s})$ & $1200(\mathrm{w})$ & $432(\mathrm{~m})$ & $488(\mathrm{w})$ & $332(\mathrm{w})$ & $482(\mathrm{~s})$ & $15390,16000,20835,21210$ \\
8 & $1615(\mathrm{~s})$ & $1222(\mathrm{w})$ & $382(\mathrm{w})$ & $510(\mathrm{w})$ & $346(\mathrm{~m})$ & $500(\mathrm{~m})$ & $13338,14612,15788$ \\
9 & $1623(\mathrm{~m})$ & $1209(\mathrm{w})$ & $412(\mathrm{~m})$ & $490(\mathrm{w})$ & $316(\mathrm{~s})$ & $504(\mathrm{~m})$ & - \\
10 & $1610(\mathrm{~m})$ & $1218(\mathrm{~m})$ & $426(\mathrm{~s})$ & $519(\mathrm{w})$ & $321(\mathrm{~s})$ & $432(\mathrm{~m})$ & - \\
\hline
\end{tabular}

${ }^{1}$ H NMR spectra: The ${ }^{1} \mathrm{H}$ NMR spectra were recorded on a Bruker- Avence $300 \mathrm{MHz}$ spectrometer in DMSO$\mathrm{d}_{6}$ at room temperature which confirms the suggested structures of the ligands (Fig. 1) (Tas et al., 2009). The ${ }^{1} \mathrm{H}$ NMR spectra of the $\mathrm{L}_{1}$ and $\mathrm{L}_{2}$ do not give any signal corresponding to acetylacetone or acetylacetanilide and hydrazine protons.

Electronic spectra and magnetic moments: The values of magnetic moment of Co (II) complexes (No. 1 and 6) is (4.22 and 4.01) B.M. respectively. The $\mathrm{Ni}(\mathrm{II})$ complexes (No. 2 and 7) show a diamagnetic moment and the electronic spectra of these complexes show bands at (15386-16000 $\left.\mathrm{cm}^{-1}\right)$ and $\left(20835-21146 \mathrm{~cm}^{-1}\right)$.
The $\mathrm{Cu}$ (II) complexes (No. 3 and 8) show a magnetic moment (1.61 and 1.80) B.M. respectively and the electronic spectrum showed abroad band at $\left(14612 \mathrm{~cm}^{-1}\right)$.

The $\mathrm{Zn}(\mathrm{II})$ and $\mathrm{Cd}(\mathrm{II})$ complexes (No. 4, 5, 9 and 10) show a diamagnetic properties and do not display any d-d transition.

Theoretical calculations: theoretical studies have been carried out to investigate the optimized geometries by calculating the steric energies (Table 4) and to investigate the bonding sites in addition to presence (or not) of M-M bonding in all complexes. 
Am. J. Applied Sci., 7 (5): 628-633, 2010

Table 4: Computational steric energies of the ligands and their complexes

\begin{tabular}{lccc}
\hline No. & $\begin{array}{c}\text { Steric energy } \\
\left(\mathrm{Kcal} \mathrm{mol}^{-1}\right)\end{array}$ & No. & $\begin{array}{c}\text { Steric energy } \\
\left(\mathrm{Kcal} \mathrm{mol}^{-1}\right)\end{array}$ \\
\hline $\mathrm{L}_{1}$ & 15.4373 & 5 & 20.4352 \\
$\mathrm{~L}_{2}$ & 13.1292 & 6 & 69.3639 \\
1 & 82.7444 & 7 & 44.6007 \\
2 & 119.6799 & 8 & 192.1933 \\
3 & 213.6190 & 9 & 27.9856 \\
4 & 17.2006 & 10 & 18.5688 \\
\hline
\end{tabular}

\section{DISSCUSION}

IR-spectra: The most important band which appeared at 1642 and $1636 \mathrm{~cm}^{-1}$ due to $v(\mathrm{C}=\mathrm{N})$ stretching in the free ligand is shifted to the lower field in the prepared complexes. This is usually indicates that the $(\mathrm{C}=\mathrm{N})$ groups of the ligands are involved in coordination with metal atom through the azomethine nitrogen atom (Sallomi and Al-Shaheen, 1994). Another important band which appeared at 1243 and $1236 \mathrm{~cm}^{-1}$ due to $v(\mathrm{C}-\mathrm{O})$ stretching in the free ligand is shifted to the lower field in the prepared complexes. This is usually indicates that the (C-O) groups of the ligands are involved in coordination with metal atom through deprotonation of the alcoholic groups (Patton and Taylor, 1974).

In addition to these changes, in the spectra of all complexes, new bands were observed at about (440$\left.454 \mathrm{~cm}^{-1}\right)$ and $\left(80-510 \mathrm{~cm}^{-1}\right)$ attributed to $v(\mathrm{M}-\mathrm{N})$ and $v(\mathrm{M}-\mathrm{O})$ stretching vibration, respectively. This represents a further evidence for the coordination of the ligands through both azomethine nitrogen and oxygen atoms (Nakamato, 1997).

Furthermore, the IR spectra of the all complexes showed another bands were observed at about (272-346 $\left.\mathrm{cm}^{-1}\right)$ and $\left(418-510 \mathrm{~cm}^{-1}\right)$ which may be due to $v(\mathrm{M}-\mathrm{Cl})$ and $v\left(\mathrm{M}-\mathrm{OH}_{2}\right)$ stretching vibration, respectively (Bayoumi et al., 2001).

${ }^{1}$ HNMR-Spectra: The ${ }^{1}$ HNR of the hydroxyl part in the ligands possesses one type of protons and will show two doublets. The spectra of the ligands show broad peak as singlet at $14.71 \mathrm{ppm}$ for $\mathrm{L}_{1} \mathrm{H}$ and at $13.93 \mathrm{ppm}$ for $\mathrm{L}_{2} \mathrm{H}$, characteristic of intermolecular hydrogen bonded $\mathrm{OH}$ proton. In the ${ }^{1} \mathrm{H}$ NMR spectra of the ligands, the chemical shifts observed at $\delta 3.81 \mathrm{ppm}$ for $\mathrm{L}_{1} \mathrm{H}$, characteristic also of intermolecular hydrogen bonded $\mathrm{NH}$ proton, but the peak at $\delta 3.12 \mathrm{ppm}$ in $\mathrm{L}_{2} \mathrm{H}$ spectra is assigned to the proton of $\mathrm{N}=\mathrm{C}-\mathrm{CH}_{3}$. The peaks at $1.96 \mathrm{ppm}$ and at $2.12 \mathrm{ppm}$ are assignable to the protons of $\mathrm{C}=\mathrm{C}-\mathrm{CH}_{3}$ for $\mathrm{L}_{1} \mathrm{H} \mathrm{a}_{\mathrm{n}} \mathrm{d} \mathrm{L}_{2} \mathrm{H}$, respectively. The protons of $\mathrm{C}-\mathrm{CH}=\mathrm{C}$ for $\mathrm{L}_{2} \mathrm{H}$ and $\mathrm{L}_{2} \mathrm{H}$ arises at 3.63 and $4.84 \mathrm{ppm}$, respectively.
Table 5: Some selected calculated parameters of the complex (5), $\left[\mathrm{Cd}_{2} \mathrm{~L}_{1} \mathrm{Cl}_{2}\left(\mathrm{H}_{2} \mathrm{O}\right)_{2}\right]$

\begin{tabular}{llr}
\hline & Selected calculated parameters & \multicolumn{1}{c}{ Value } \\
\hline Bond angles $\left(^{\circ}\right)$ & $\mathrm{N}_{1}-\mathrm{Cd}_{1}-\mathrm{Cl}_{1}$ & 83.0000 \\
& $\mathrm{~N}_{1}-\mathrm{Cd}_{1}-\mathrm{O}_{1}$ & 82.0000 \\
& $\mathrm{O}_{1}-\mathrm{Cd}_{1}-\mathrm{Cl}_{1}$ & 87.0000 \\
& $\mathrm{O}_{3}-\mathrm{Cd}_{2}-\mathrm{O}_{4}$ & 98.0000 \\
& $\mathrm{~N}_{2}-\mathrm{Cd}_{2}-\mathrm{O}_{4}$ & 102.0000 \\
& $\mathrm{~N}_{2}-\mathrm{Cd}_{2}-\mathrm{Cl}_{2}$ & 85.0000 \\
Bond lengths $\left(\mathrm{A}^{\circ}\right)$ & $\mathrm{Cd}_{1}-\mathrm{N}_{1}$ & 1.9085 \\
& $\mathrm{Cd}_{1}-\mathrm{O}_{1}$ & 1.8394 \\
& $\mathrm{Cd}_{2}-\mathrm{O}_{3}$ & 1.8000 \\
& $\mathrm{Cd}_{2}-\mathrm{N}_{2}$ & 1.8513 \\
& $\mathrm{~N}_{1}-\mathrm{N}_{2}$ & 1.4250 \\
\hline
\end{tabular}

Electronic-spectra: The electronic spectrum (Table 3) of $\mathrm{Co}$ (II) complexes shows a strong band in the visible region at 13800 and $13815 \mathrm{~cm}^{-1}$ respectively corresponding to transition ${ }^{4} \mathrm{~A}_{2}(\mathrm{~F}) \rightarrow{ }^{4} \mathrm{~T}_{1}(\mathrm{P}) \quad\left(\mathrm{v}_{3}\right)$ in tetrahedral environment for $\operatorname{Co}(\mathrm{II})$ while $\left(v_{1}\right),\left(v_{2}\right)$ was not observant due to instrumental limit (Wilkinson, 1987).

The bands in the electronic spectra of $\mathrm{Ni}(\mathrm{II})$ complexes (No. 2 and 7) were attributed to ${ }^{1} \mathrm{~A}_{1} \mathrm{~g} \rightarrow{ }^{1} \mathrm{~A}_{2} \mathrm{~g}$ and ${ }^{1} \mathrm{~A}_{1} \mathrm{~g} \rightarrow{ }^{1} \mathrm{~B}_{1} \mathrm{~g}$. which is consistent with square planar geometry for Ni(II) complexes (Singh et al., 1989).

According to the band in $\mathrm{Cu}(\mathrm{II})$ complexes electronic spectrum which is assigned to ${ }^{2} \mathrm{~B}_{1} \mathrm{~g} \rightarrow{ }^{2} \mathrm{Eg}$ transition, is consistent with square planner geometry around $\mathrm{Cu}(\mathrm{II})$ complexes (Wilkinson, 1987).

The $\mathrm{Zn}(\mathrm{II})$ and $\mathrm{Cd}(\mathrm{II})$ complexes due to their diamagnetic properties and no $\mathrm{d}-\mathrm{d}$ transitions and based on stoichiometry of these compleses and elemental analysis,they are four coordinated, which could be either tetrahedral or square planer, however, tetrahedral geometry is the more preferred stereochemistry for this $\mathrm{Zn}(\mathrm{II})$ and $\mathrm{Cd}(\mathrm{II})$.

Theoretical studies: Theoretical calculations (Geary, 1971; Allen et al., 1991; Rappe and Casewit, 1997) have paid a considerable attention to the characterization and inferences of geometrical optimization of the prepared complexes, therefore we could obtain the optimized geometry for each complex by computing the minimum steric energy and the theoretical physical parameters, such as, bond length and bond angles using MM2CS ChemOffice version 9.0 molecular modeling program. The steric energies of the prepared complexes are listed in Table 4; according to these values we could determine the bonding via imine and hydroxyl groupsalso there is no M-M bonding mode The optimized structures of complex 5 and 7 (Fig. 3 and 4, respectively) were drawn here, as an example, with some selected calculated parameters in coordination sphere (Table 5 and 6 respectively). 


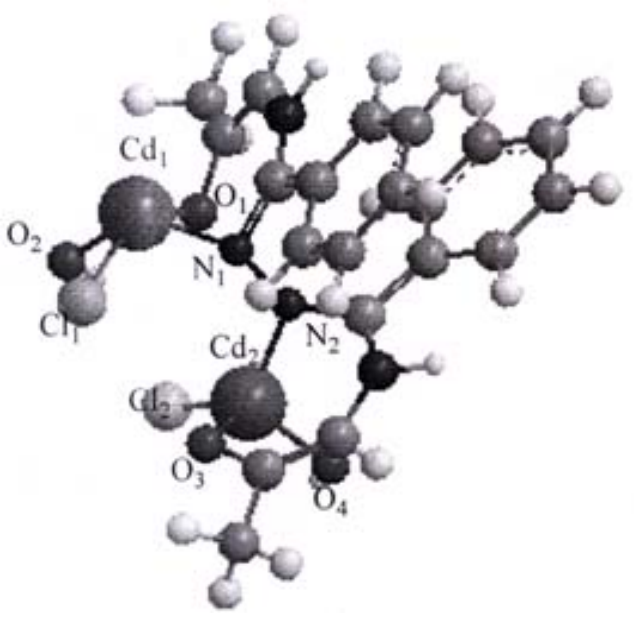

Fig. 3: Configuration of complexes (5) $\left.\mathrm{Cd}_{2}\left(\mathrm{~L}_{1}\right) \mathrm{Cl}_{2}\left(\mathrm{H}_{2} \mathrm{O}\right)_{2}\right]$, optimized by MM2 CS molecular modeling program package

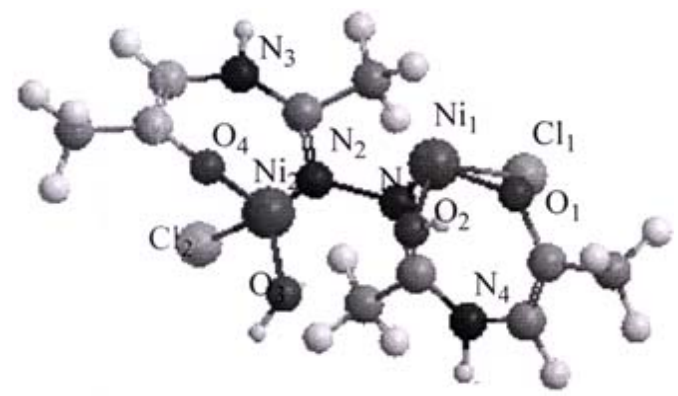

Fig. 4: Configuration of complexes (7) $\left[\mathrm{Ni}_{2}\left(\mathrm{~L}_{2}\right) \mathrm{Cl}_{2}\left(\mathrm{H}_{2} \mathrm{O}\right)_{2}\right]$, optimized by MM2 CS molecular modeling program package

Table 6: Some selected calculated parameters of the complex (7), $\left[\mathrm{Ni}_{2} \mathrm{~L}_{2} \mathrm{Cl}_{2}\left(\mathrm{H}_{2} \mathrm{O}\right)_{2}\right]$

\begin{tabular}{lll}
\hline & $\mathrm{Selected}$ calculated parameters & Value \\
\hline Bond angles $\left(^{\circ}\right)$ & $\mathrm{N}_{1}-\mathrm{Ni}_{1}-\mathrm{Cl}_{1}$ & 93.0000 \\
& $\mathrm{O}_{1}-\mathrm{Ni}_{1}-\mathrm{O}_{2}$ & 78.0000 \\
& $\mathrm{Cl}_{1}-\mathrm{Ni}_{1}-\mathrm{O}_{2}$ & 84.0000 \\
& $\mathrm{~N}_{2}-\mathrm{Ni}_{2}-\mathrm{Cl}_{2}$ & 98.0000 \\
& $\mathrm{O}_{3}-\mathrm{Ni}_{2}-\mathrm{O}_{4}$ & 95.0000 \\
& $\mathrm{~N}_{2}-\mathrm{Ni}_{2}-\mathrm{O}_{4}$ & 87.0000 \\
Bond lengths $\left(\mathrm{A}^{\circ}\right)$ & $\mathrm{N}_{1}-\mathrm{Ni}_{1}$ & 1.1103 \\
& $\mathrm{O}_{1}-\mathrm{Ni}_{1}$ & 1.8211 \\
& $\mathrm{~N}_{2}-\mathrm{Ni}_{2}$ & 1.0362 \\
& $\mathrm{O}_{4}-\mathrm{Ni}_{2}$ & 1.7498 \\
& $\mathrm{~N}_{1}-\mathrm{N}_{2}$ & 1.5562 \\
\hline
\end{tabular}

\section{CONCLUSION}

New hydrazine Schiff-base ligands, $\mathrm{LnH},(\mathrm{n}=1$ or 2) with their dinuclear metal complexes of the type $\left[\mathrm{M}_{2}\left(\mathrm{~L}_{\mathrm{n}}\right) \mathrm{Cl}_{2}\left(\mathrm{H}_{2} \mathrm{O}\right)_{2}\right]$ were synthesized. The structure of the ligands and their complexes were determined by several methods such as FT-IR, UV-Vis, ${ }^{1} \mathrm{H}$ NMR, elemental analysis, molar conductivities, magnetic susceptibility, in addition to theoretical calculation using MM2modeling program. The tetradentate Schiffbase ligands ere used as stabilizer ligands for dinuclear metal complexes and according to the measurements and theoretical calculations, the $\mathrm{Co}(\mathrm{II}), \mathrm{Zn}$ (II) and $\mathrm{Cd}(\mathrm{II})$ complexes have tetrahedral geometries while $\mathrm{Ni}(\mathrm{II})$ and $\mathrm{Cu}(\mathrm{II})$ complexes have square planar geometries around the central metal atom.

\section{REFERENCES}

Allen, F.H., J.E. Davies, J.J. Galloy, D. Johnson and O. Kennard et al., 1991. The development of versions 3 and 4 of the Cambridge structural database system. J. Chem. Inform. Comp. Sci., 31: 187-204. http://cat.inist.fr/?aModele $=$ afficheN\&cpsidt $=4326$ 613

Al-Razaq, E.A., O.M. Al-Ramadany, M.A. Al-Shama and T.A.K. Al-Allaf, 2005. Synthesis and characterization of organ silicon (IV) complexes with some Schiff base derivatives. Int. J. Chem. Sci., 3: 253-262.

Bayoumi, H.A., E.M. Shouky and M.M. Mostafa, 2001. N-2-[4,6-dimethylpyridyl]-N'-phenylthiourea (HDMPyPt) transition metal complexes. Synth. React. Inorg. Metal-Organic Nano-Metal Chem., 31: 579-597. DOI: 10.1081/SIM-100104788

Bedioui, F., 1995. Zeolite-encapsulated and clayintercalated metal porphyrin, phthalocyanine and Schiff-base complexes as models for biomimetic oxidation catalysts: An overview Coord. Chem. Rev., 144: 39-68. http://cat.inist.fr/?aModele=afficheN\&cpsidt=11183111

Brown, S.L., J. Sasaki, H. Kandori, A. Maeda, R. Meedleman and J.K. Lanyi, 1995. Glutamic acid 204 is the terminal proton release group at the extracellular surface of bacteriorhodopsin. J. Biol. Chem., 270: 27122-27126. PMID: 7592966

De Geest, D.J., A. Noble, B. Moubaraki, K.S. Murray, D.S. Larsen and S. Brooker, 2007. Dicopper(II) complexes of a new pyrazolate-containing Schiffbase macrocycle and related acyclic ligand. Dalton Trans., 28: 467-475. PMID: 17213932

Geary, W.J., 1971. The use of conductivity measurements in organic solvents for the characterization of coordination compounds. Coord. Chem. Rev., 7: 81-122. http://www.garfield.library.upenn.edu/classics1981 /A1981LG20000001.pdf 
Knight, J.C., A.J. Amoroso and P.C. Edwards, 2007. $\mathrm{Bis}\{\mathrm{N}$-[bis(6-bromopyridin-2-yl)methylene$\kappa \mathrm{N}]$ ethane-1,2-diamine- $\left.\kappa^{2} \mathrm{~N}, \mathrm{~N}^{\prime}\right\}$ nickel(II) bis(perchlorate). Acta Cryst., E63: m1046-m1047. DOI: $10.1107 / \mathrm{S} 1600536807010653$

Maurya, M.R., D.C. Antony, S. Gopinathan and C. Gopinathan, $1995 . \quad$ Binuclear Dioxomolybdenum(VI) Complexes of FlexiblyBridged Hexadentate Tetraanionic Schiff's Bases Derived from Methylene- or Dithiobis(salicylaldehyde) and S-Methyldithiocarbazate or S-Benzyldithiocarbazate. Bull. Chem. Soc. Jap., 68: 554-558.

http://cat.inist.fr/?aModele $=$ afficheN\&cpsidt $=1107$ 8011

Nakamato, K., 1997. Infrared and Raman Spectra of Inorganic and Coordination Compounds. 5th Edn., Wiley-Interscience Publication, New York, ISBN: 10: 0471163929, pp: 400.

Patton, R.D. and L.T. Taylor, 1974. Iron (III) complexes of pentadentate ligands. Inorg. Chem. Acta, 8: 191-193. DOI: 10.1016/S00201693(00)92614-8

Rappe, A.K. and C.J.R. Casewit, 1997. Molecular Mechanics Across, Chemistry. University Science Books, ISBN: 10: 0935702776, pp: 444.

Rai, H.C. and B.N. Sharma, 1995. Cobalt(II), Nickel(II) and Copper(II) Complexes with 2-Hydroxyimino4,5-Diaza-3-phenyl-6-Amino-6-Mercapto-3-

Hexene. Asian J. Chem., 7: 775-780. http://direct.bl.uk/bld/PlaceOrder.do?UIN=003167

$823 \&$ ETOC $=$ RN\& from $=$ searchengine
Sallomi, I.J. and A.J. Al-Shaheen, 1994. Complexes of hydrazide Schiff bases. Trans Met. Chem., 19: 275-276. DOI: 10.1007/BF00139091

Singh, N., N.K. Singh and C. Kaw, 1989. Synthetic and spectroscopic studies of xanthato-bridged heterobimetallic complexes containing diamagnetic and paramagnetic metal ions. Bull. Chem. Soc. Jap., 62: 3328-3333. http://cat.inist.fr/?aModele $=$ afficheN\&cpsidt $=6735$ 425

Tas, E., I.H. Onal, I. Yilmaz, A. Kilic and M. Durgun, 2009. Synthesis, structural characterization, electrochemistry and spectroelectrochemistry of dinuclear copper(II) metal complexes stabilized by a tetradentate NOOO salicylaldimine ligands. J. Mol. $\quad$ Struct., 927: 69-77. http://cat.inist.fr/?aModele $=$ afficheN\&cpsidt $=2159$ 1235

Vigato, P.A., S. Tamburini and L. Bertols, 2007. The development of compartmental macrocyclic Schiff bases and related polyamine derivatives. Coord. Chem. Rev., 251: 3311-1492. DOI: 10.1016/j.ccr.2006.11.016

Wilkinson, G., 1987. Comprehensive Coordination Chemistry: The Synthesis, Reactions, Properties and Applications of Coordination Compounds. 1st Edn., Pergamon Press, Oxford, ISBN: 10: 0080437486, pp: 7. 